\title{
総説
}

\section{The Role of Rheology in Food Science}

by

Sachio Matsumoto

(College of Agriculture, University of Osaka Prefecture, Mozu-umemachi, Sakai, Osaka 591)

\section{食品科学におけるレオロジーの役割}

\author{
松 本 幸 雄*
}

(原稿受理：1978年 2 月14日)

\section{1.は じめに}

1977年む押しつまった12月19日から 4 日間, ロンドン大学クイ ーンエリザベスコレッジで, 「食品のテクスチャーとレオロジー に関する国際シンポジウム」が開かれた。日本を含む17か国から， 扔よそ80名の参加者を得て，26の講演とそれに対する討論が行わ れたが，夫人に手を引かれててれに参加した Dr. Scott Blair の 姿が印象的であった。半世紀以上をレオロジーとともに過した彼 は, 現在ほとんど視力を失っているのである。てのシンポジゥム の詳細は, Dr. Shermanの編集により後日モノグラフとして刊行 される予定であるが，討論の対象となった主題は，あらまし次の 3 項目に大別されるであろう。すなわち，「食品のテクスチャー に対する感覚的・心理学的アプローチ」,「食品のテクスチャーの 客観的測定法」および「各種食品あるいは食品モデル系の組織・ 構造とレオロジー的性質との関係」である.てのような内容は, 5 年前から我が国で例年開催されている食品の物性に関するシン ポジゥムのそれとも一致する1) 2).

食品科学は, 生物化学, 微生物学, 栄養生理学, 高分子学, 化 学工学等の諸学科を背景として成立する極めて総合的な研究分野 の一つであり，てれに上記のような主題を推してレオロジーがか かわりを持つととに何の不思議もない，それぞころか，食品材料 がレオロジー研究の対象となった歴史は古く ${ }^{3)}$, 前述のような国 際シンポジゥムの開催も, 地味で不定期なあのではあるにせよ, 既に過去数回に及んでいるのである.しかし，食品レオロジーの 分野を創設せよといった主張を少なくと屯筆者は聞いたととがな いし，またその必要性屯筆者には感じられない，むしろ，理論的 背景と方法論において, 材料の種類を超越した普遍性のある研究 分野の一つであるレオロジーが, 何故食品科学の分野とかかわり

* 大阪府立大学農学部農芸化学科 堺市百舌鳥梅町
合っているのかという事情を一般化して, 食品科学に析出する特 徵を科学全体の中で位置づけ認識することの方が重要であると考 えるのである．乙のような立場に立って，本稿では表題の意味を 微力ながら考えてみたい.

\section{2. 食品に対する認識と評価}

人の知的活動の一つである科学の場で, 人の持つ情緒的, 感覚 的あるいは観念的な側面は疎外され勝ちである。，その姿勢は理性 的ではあるが, 一般からは知性のでう慢であるとして強く非難さ れる場合むある。そして，いわゆる科学の場で，情緒と知性を調 和させるととは大変困難である. 食品は, 極めて科学的に取り扱 われる一方, 感覚的にも非常に厳しく評価される材料である. 将 来の人口増加之農業生産の限界がいろいろな立場から予測されて いる現在, 乙の問題に対する理性的な処理法の一つとも言うべき 微生物による食糧資源の生産が害用化の段階にまできて, 我が国 ではこれが社会問題になった。科学的論理性が, 食品の動向を律 する唯一の価值基準たりえないことを示す一例である ${ }^{4), 5)}$.

人は，それぞれの生活の中である範囲内の材料によって調理さ れた食事をとり続ける。すなわち, 各人の食生活はほぼ定式化さ れているのである. その中で, 程度の差こそあれ個々の食品に対 する固有の概念が蓄積され，人それぞれの主観的，観念的なし (啫)好が形成されるようになる.乙のような主観的判断によって 導汃れる食品の評価においては, 個人の意識や連想が複雑に作用 するのである，乙のような感覚的評価の基準になると考えられる あのを, 食感要素と呼ぶ。 アメリカの Szczesniak吕は, 種々の 食品名に対する人々の反応連想語を収集し, 整理して, 食感要素 が表 1 に示すような諸特性によって構成されることを明らかにし た。そてに表現されている数字そのあのに，人種や個人の環境を 超えた普遍性があるか否かについては問題があるにせよ，食感要 


\begin{tabular}{|c|c|c|}
\hline 性 & 男性の場合 & 女性の場合 \\
\hline テクスチャー & $27.2 \%$ & $38.2 \%$ \\
\hline 口で感じる香り(フレーバー) & 28.8 & 26.5 \\
\hline 色 & 17.5 & 13.1 \\
\hline 形 & 21.4 & 16.6 \\
\hline 鼻で感じる香り(アロマ) & 2.1 & 1.8 \\
\hline その 他 & 3.0 & 3.8 \\
\hline
\end{tabular}

素の内容を分析しようとしたとの試みは高く評価されている．同 時に，「歯でたえ」,「口当たり」,「舌ざわり」等の語感に相当す る食品のテクスチャーが, 男女とも食感要素の重要な部分を構成 していることに，多くの注目が集まったのである.

食品の感覚的評価に対応して, 客観的に測定されるべき食品の 諸性質は多様であり，その大部分は人間の情緒的な生理感覚の問 題も含めて, 今後の研究や食品研究者の理解にまたねばなら好も のであるが, 食感要素を構成する諸特性のうちのテクスチャーに ついては, てれが食品のレオロジ一的性質やサイコレオロジーと 直接かかわっていることが明らかであり，同時に食品の組織・構 造と関連した問題であある. これについては既に幾つかの研究7) があり，前述のような国際シンポジウムが開催される一方，1969 年からオランダで Journal of Texture Studies が刊行されるよう になった。

\section{3. 食品のテクスチャー}

既に曽根 ${ }^{8}$ が指摘しているように，テクスチャーという述語の 持つ意味は広い。いずれにせよ, 食品の力学的性質が感覚的に評 価される問題を取り扱うのであるから, 知覚生理学 ${ }^{9}$ やサイコレ オロジーがその中で重要な位置を占める一方, 各種食品のレオロ ジー的性質を測定し記述するための方法論や, 食品のような多成 分不均一混合系の分散状態とそのレオロジー的性質との関係等が,
表2 Szczesniak のテクスチャープロフィル11)

\begin{tabular}{|c|c|}
\hline クラス & 一次特性 二次特性 \\
\hline 力学特性 & 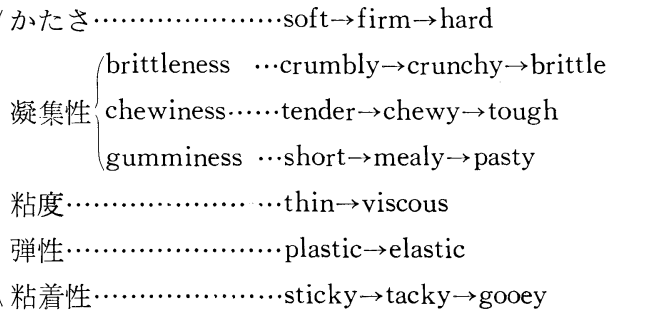 \\
\hline 幾何特性 & $\begin{array}{l}\text { 粒子径と形……….... gritty, grainy, coarse, etc. } \\
\text { 粒子形と会合状態....fibrous, cellular, crystalline, etc. }\end{array}$ \\
\hline その 他 & $\left\{\begin{array}{l}\text { 水分含量 } \cdots \cdots \cdots \cdots \cdots \cdot \cdots \text { dry } \rightarrow \text { moist } \rightarrow \text { wet } \rightarrow \text { watery } \\
\text { 脂肪含量 }\left\{\begin{array}{l}\text { oiliness } \cdots \cdots \text { oily } \\
\text { greasiness } \cdots \text { greasy }\end{array}\right.\end{array}\right.$ \\
\hline
\end{tabular}

基礎的な背景としてテクスチャーの問題の中で取り上げられなけ ればならない。

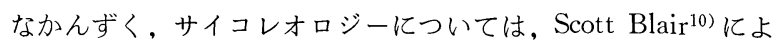
ってその研究の端緒が開かれたことはよく知られているが, その

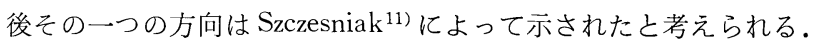
彼女は, 人の感覚的判断は言葉で表現され他者に伝達されて客観 化されることに注目し, 前述の食感要素の分析に用いた食品名に 対する反応連想語の中から更にテクスチャーに関係のある表現を 選び，てれらを整理して客観的に測定しうる諸特性と対置させた テクスチャープロフィルをつくった。サイコレオロジーを, 感覚 的・主観的な評価とレオロジ一的・客観的な測定結果との相関々

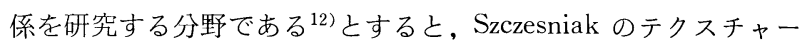
プロフィルは, 文字どおりサイコレオロジー研究の輪郭を与える ための一つの試みではある(表 2 ). 実際に, 彼女のこのような提 案は種々の論議を呼ぶ材料となり，例えば我が国では日本語によ るテクスチャープロフィル作製の契機を与えた ${ }^{13), 14)}$.なぜなら,

表 3 日本語によるテスクチャー用語の整理 ${ }^{14)}$

第 П 因子型

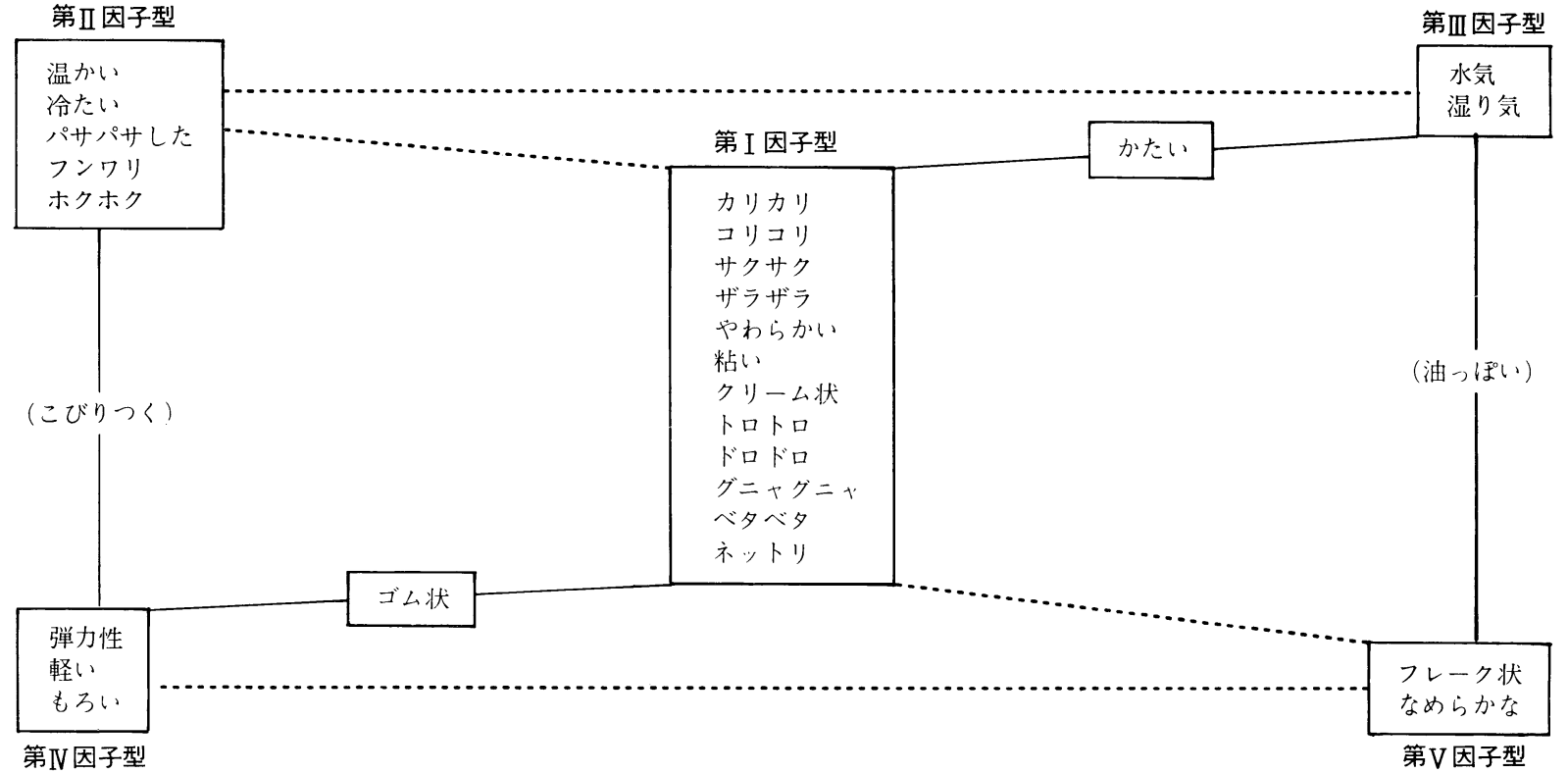


表4 Sherman のテクスチャープロフィル16)

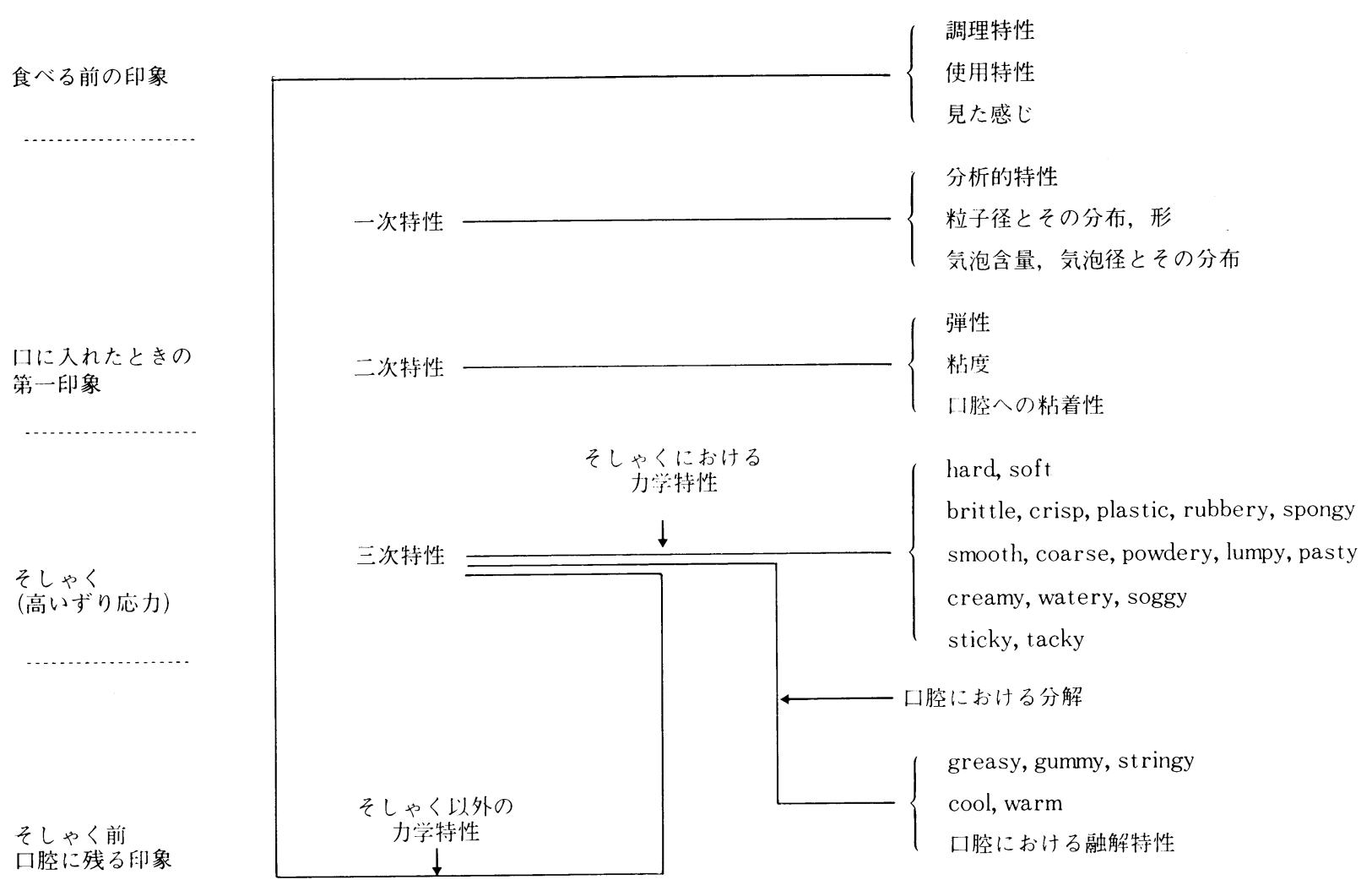

感覚的判断に関する表現には, 到底他国語に翻訳しえない微妙な ニュアンスが含まれるからである。しかし, 日本語にはその言語 的特徵として擬声・擬態語が多く, 収集された日本語によるテク スチャープロフィルの作製が困難であったと報告されている．結 局, 表 3 に示すような因子分析による整理法が提案され ${ }^{13)}$, また 使用する収集語に制限を設ける方法が考察された ${ }^{15)}$. 一方, 英国 の Sherman ${ }^{16)}$ は, 人の感覚に対応させるべき客観的諸量の物理 学的意味は明確でなければならないとする立場, および食感要素 は食べる動作の中から生じるところの動的な要因を含むとする見 解に立って, 表 4 のようなテクスチャープロフィルを提出した. Szczesniak のそれ（表 2) に示されている力学特性のうち, かた さ, 凝集性, 粘着性等は, 後述するような試験機（テクスチュロ メーター）によって得られる值が用いられるが，このような值に 物理学的意味を見いだすことが困難であるからである。

結局, 前述のように食品のテクスチャーは, 口腔における知覚 機能の問題から, サイコレオロジー, レオロジー, コロイド科学, あるいは言語学の分野にわたる問題が関連し合った研究の対象で ある、その中で, 方法論としてのレオロジーの役割は極めて大き い.

\section{4. 口腔における粘度知覚}

この項で取り上げるのは, Wood ${ }^{17)}$ およびSherman ら ${ }^{18) ~ 20) か ゙ ~}$ 行った液状食品についてのサイコレオロジカルな一連の研究例で ある。スープのような液状食品にも，人々に好まれる粘度がある。 しかし, 多くの液状食品は非ニュートン流体であるから, そ机ぞ れのレオロジー的性質は少なくともずり速度〜ずり応力の関係で 記述されなければならない。ところが，人は口腔において液体の
ニュートン性, 非ニュートン性を識別せず, 液体の粘度差のみを 知覚することが Wood ${ }^{17)}$ にって見いだされた。このととは，人 の口腔がある一定のずり速度〜ずり応力範囲で粘度を知覚する生 理機能を有することを示唆している。そてで Sherman ら ${ }^{18), 19)}$ は， 液体の粘度の感覚的な弁別に優れたパネルを26名（女性21名, 男 性 5 名）選び, 多くの液状食品を用いて二ュートン液体と非二ュ 一トン液体との口腔に打ける粘度の比較知覚を試みた。例えば, 図 1 はこの実験に用いた A，B，CN6 種類のニュートン液体と 1 種類の shear thinning 型非ニュートン液体 Xの流動曲線を模式 的に示したものである. 後者の見掛けの粘度はずり速度の増加と

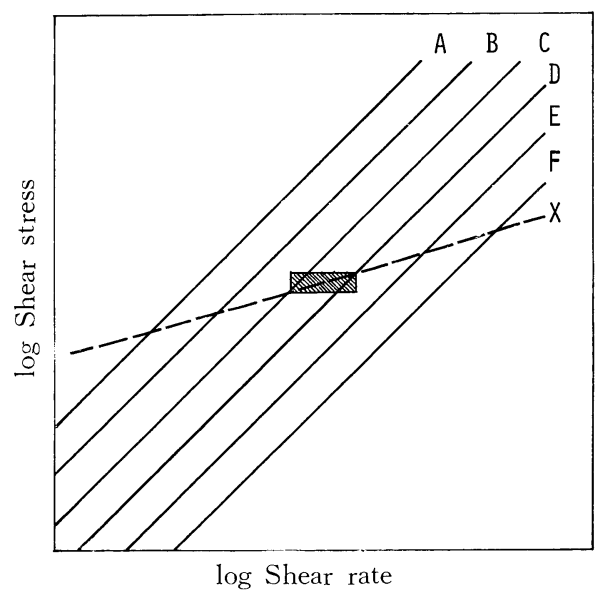

図 1 二ュートン液体と非ニュートン液体の粘性を比較 することにより粘度知覚の際のずり速度〜ずり応 力範囲を判定する方法の模式図 (本文参照) ${ }^{18)}$ 
ともに低下するから，客観的にはニュートン液体と非ニュートン 液体の粘度を比較することが全く無意味であることは言うまでも ない．と乙ろがての実験によれば, 先のパネルは, 例えば図 1 の非 ニュートン液体の粘度がニュートン液体のうちのCないし D試料 の粘度と同じであると判断するのである，そうすると，ての例で は, 人が口腔で粘度を知覚するときのずり速度〜ずり応力範囲が 図1の斜線の部分に相当することが示唆される.そこで, Sherman らは，あらゆる液状食品の流動曲線を同心円筒型回転粘度計で求 めておき。次いでてれらの試料を種々組み合わせながら先のパネ ルを用いて図 1 のような官能検査を多数反復した。その結果，図 2 に示すように, 人が粘度を知覚する際のずり速度〜ずり応力範 囲が、流動曲線を表す座標上に得られたのである。この結喿は， 人が口腔内で液状食品に対して無意識に作用させるずり応力が, 試料粘度に対応して変化することを示しているが，口腔の動作そ

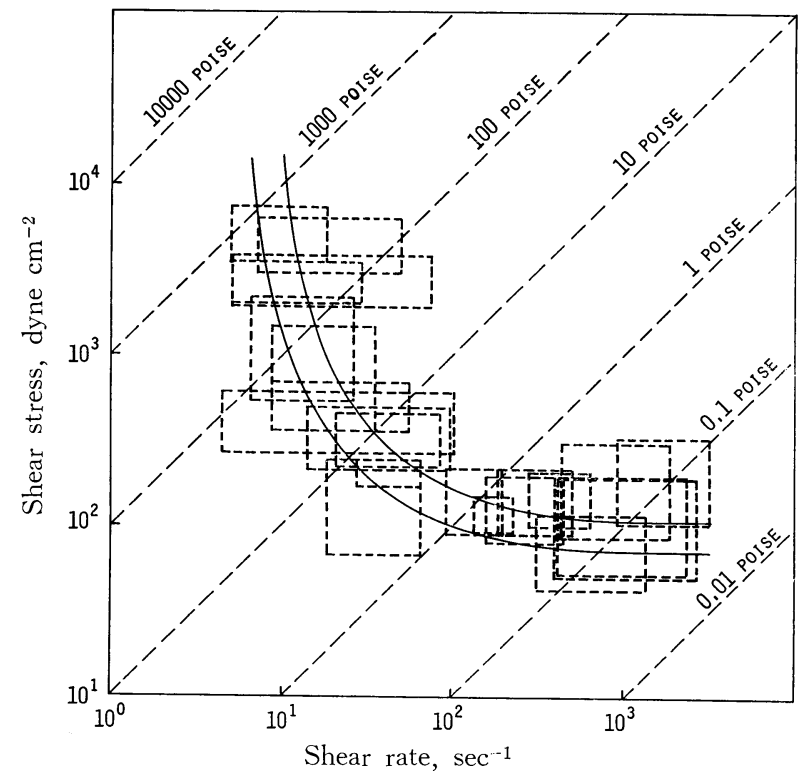

図 2 人が口腔に沶いて液体食品の粘度を知覚する際の ずり速度〜ずり応力範囲 ${ }^{19}$

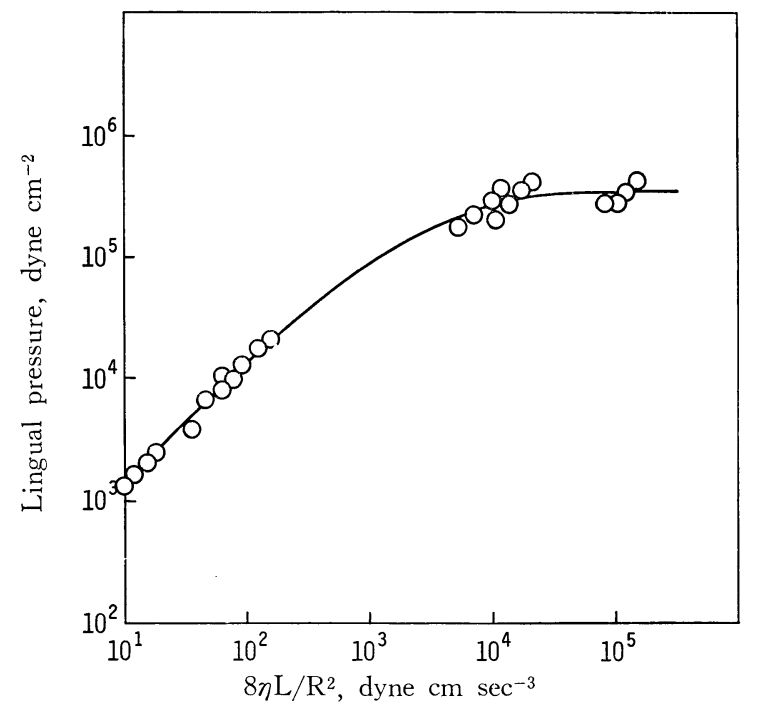

図 3 液体食品の粘度と人が口腔に招いて液状食品に加 える舌の圧力との関係 (本文参照 ${ }^{20)}$
のものは非常に複雑であるので, 乙の結果の意味を単純に解釈す ることはできないだろう。そこで Sherman ら ${ }^{20)}$ は，種々の粘度 の液体を内径の異なる 4 種類の毛細管に詰め, その一端に乳首を 取り付けて人の口腔に挿入し，舌を使って飲み込む動作をさせた ときの液体の毛細管内の流速を高速度カメラで記録して, 粘度と ずり応力との関係を測定するととを試みた．図 3 はその結果で, 横軸の $\eta$ は試料粘度， $L$ は毛細管の長さ， $R$ は同じく半径であ る。乙のような実験から， 口腔動作によって生じるずり応力は液 体の粘度ととあに増大するが，その值はやがて一定值に到達する ことがわかる，恐らく，高粘度の液状食品に対しては，唾液によ る希釈や阻しゃく等の生理的な動作が加わるものと思われる。

この項で述べた一連の実験は, 人の感覚が物理学的次元の明確 な座標上に示された点で注目され，また生物レオロジーへのアプ ローチが必要であるととを示唆するものとして重要な研究である と考えられている21).

\section{5. 食品のテクスチャ一測定法}

食品のレオロジー的性質，すなわちひずみ，応力，時間の関係 を測定するための原理に特別のものはない，しかし，その一般的 な原理を，多様な形態を有する食品に実際に適用するためには， 測定装置に種々の工夫を凝らす必要がある．特に，多くの食品材 料に現れる形態として, 水分含量が多く保型性はあっても非常に 軟質であること，および組織的に極めて不均一な状態のものであ ること、等が挙げられよう.そのために，試料に一定のひずみや 応力を加え続けることが困難な場合が多い，測定法の詳細につい ては，幾つかの文献を参照していただきたい(8),22) 24)．てのよう な実情から，より実用的な立場に立って，個々の食品に適合した 各種の試験機が作られ使用されてきた ${ }^{25)}$. これら試験機の最近の

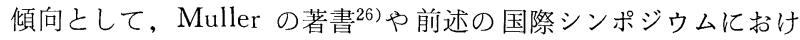
るVoisey の講演 ${ }^{27)}$ にると、インストロンの装置を基本に用い て試料を定速度で圧縮, 伸張あるいは切断する際の付属装置に種 々の工夫がなされているようである.

かなり以前の乙とになるが，主観的に判断される食品のテクス チャーを可及的に客観的に測定するために試作された興味深い装 置がある ${ }^{28)}$.乙れは，一組の総入れ歯のうち下あごの部分を水平 に固定してスイレインゲージを付し，上あごの部分を上下運動さ せて人が行っている咀しゃく動作のシュミレーションを試みよう としたあのである。しかし, 試料と接触する部分が, 形状の複雑 な歯型であるととなどから，結局この装置は実用にはならなかっ たようである。その後, Szczesniak ら ${ }^{29)}$ は，乙の装置の義歯の部 分を一組のプレートとプランジャーに置き換えるととによって, 再現性のよい勗しゃく曲線を測定するのに成功した。これがテク スチュロメーターと呼ばれ，食品研究者の間で広く使用されるよ うになった武験機の原型である，すなわち，下あごの代わりに一 枚の金属性円板を固定し、試料血とする．また上あごの代わりに 一本の金属性プランジャーを試料四の上部に設け，一定周期で上 下運動させる，円板上に試料が載せられているとき，プランジャ 一の動きはこの試料を介して円板に伝えられる仕組である。その 結果, 円板が受け止める力の変化は, ごく模式的には図 4 のよう に記録されることになる。咀しゃく曲線と呼ばれるこの図形は, あち万ん試料の種類や状態に対応して変化するので, 各試料の力 学的特性をその図形から客観的仁記述することが可能になる。そ 


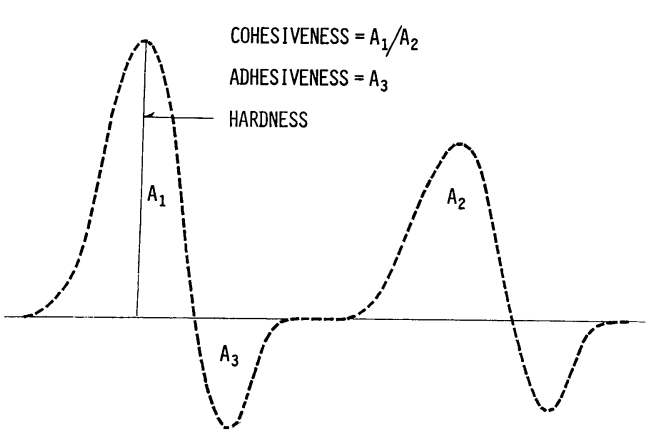

図 4 テクスチュロメーターにより得られる咀しゃ く曲線を一般化した図形29)

こでSzczesniak ら ${ }^{29}$ は，アナログ量として現れるこのような勗し ゃく曲線の第 1 ピークと第 2 ピークの各面積と $A_{1}$ と $A_{2}$ の比を 凝集性，第 1 ピークの高さをかたさ，第 1 ピーク消滅後負の位置 に現れるピークの面積 $A_{3}$ を粘着性と規定したのである。乙れら 諸特性の物理学的意味は不明確であるが, 先の表 2 のテクスチャ ープロフィルに整理されている凝集性，かたさ，粘着性等は，図 4 の咀しゃく曲線加ら求められる上述の諸量によく対応するとい $う^{30)}$ 。乙のようなととから，測定の簡便さと相まってての装置は 多くの食品研究者の注目を集め, 我が国でもかなりの量のテクス チュロメーターが導入されていると思われる。一方，ての装置の 有用性が高まるほど，咀しゃく曲線の物理学的意味を求めようと する研究者も現れ，最近 Journal of Texture Studies はこの問題 の特集号を発行している ${ }^{31)}$.いずれにせよ，咀しゃく動作には， 大変形のレオロジーの問題が深く関連してくるあのと考えられる.

\section{6. モデル系による食品材料のレオロジー的性 質の研究}

これまでに述べた食品の感覚的評価の問題はさておいても，成 分的に組織形態的に複雑な食品はやっかいな研究の対象であり, その分散状態に関する基本的な仕組や，それに伴って発現するレ オロジ一的性質を理解するためには，過渡的な手段ではあるにせ よ，比較的単純なモデル系に依存して実験を進めなければならな い場面がある。形態的なモデルに限らず，前述のように口腔で の阻しゃく動作を単純化したテクスチュロメーターが設計された (例28),29)や，生体膜の機能を明らかにするために脂質黑膜 ${ }^{32), 33) や ~}$ リポゾーム ${ }^{34), 35)}$ が調製された例のように，モデル系による研究 は多くの分野に見られるのであるが，どの場合もこの種の実験で は実在の系なり動作なりに一層アプローチさせるためのモデル系 の選択之改良が常時必要であろう。

バターやマーガリンは, 液状と結晶状の脂肪から成る油相と食 塩やタンパク質などを含んだ水相との W/O 型分散系であるが， これら油脂食品のレオロジー的性質やその温度依存性は, 伸展性 のような実用上の問題と関連して重要である.Van den Tempel ${ }^{36)}$ や曽根ら ${ }^{37)}$ は，トリステアリンと流動パラフィンを混合して調製 した可塑性脂肪のレオロジ一的性質を測定しているが，てれらの 研究は油脂食品の物性に対して基濋的な情報を与えているあのと 考えられる。また曾根 ${ }^{38}$ は, バタ一の塑性粘度が熟成によって増 加する現象を，脂肪の結晶化の問題と関連させ，金属の結晶化速 度に関する Avrami ${ }^{39)}$ の理論を用いて説明した。

中山ら ${ }^{40) \sim 44)}$ は, 食肉の加工において重要であるひき（挽）肉 やすり (摺) 身の結着性の問題を, 肉組織から分離されるミオシ
ンのゲルのレオロジー的性質に注目して一連の研究を行っている. その結果, 抽出されたミオシンに含まれるミオシン $\mathrm{A}$, アクチン および活性トロポミオシンの量が, ゲル形成能と関連して食肉の 結着力や保水性に対して重要であることが示唆された。この研究 では，試料に対してオーソドックスなレオロジ一の手法が用いら れているので得られた結果の普遍性は高く，したがって生物レオ ロジーの分野に対しても有用なモデル研究の一つになるのではな いかと思われる。

Sherman は食品研究者として著名であるが，同時にェマルショ ン系とこれに関連したコロイド・界面科学の分野についてあ造け いが深く、エマルションの基礎的研究に関する多くの論文 ${ }^{45)}$ を発 表している. 彼は, 多くの食品が複雑な分散系であることから, その一般的なモデルとしてェマルションを取り上げているのであ る. 筆者屯, 彼之の協同研究で, 均質化牛乳の粘度が未均質化牛 乳のそれよりあ高くなる現象を, 種々の分散粒子径加ら成る $\mathrm{O} / \mathrm{W}$ 型エマルションを用いて確かめたてとがある活．また，最近筆者 らは, 生体組織である食品材料のような多数の細胞で構成される 物質, 言い換えれば膜構造を有する系のモデルとして, 一連の多 相型エマルションを調製した ${ }^{47) ~ 49)}$ ．乙のものは，薄い油膜や脂 質膜に包まれた水の粒子を水の中に分散させた系であり，単純な エマルション系では観測しえない諸性質が現れる．例えば，油膜 の厚さが薄くなるほど系全体の粘度は増し, また分散水相に電解 質や糖質のような低分子物質をあらかじめ溶解しておくことによ り, 系全体のレオロジ一的性質はその濃度に著しく影響されるの である50).

小麦粉を水之混ねつして得られるいわゆる小麦粉ドウのレオロ ジー的性質は，製パンや製めん（畐）の際の工程管理に欠かせな い要因であるが, 小麦の品種は多様でありその成分組成も複雑で あるので，筆者ら ${ }^{51) ~ 53)}$ は小麦粉から可及的に純粋に抽出し乾燥 したグルテンタンパク質とデンプン粒子を再び混合し水と混ねつ した 3 成分系を調製して，そのレオロジ一的性質に対する成分濃 度や微量成分添加の影響を調べている，問題は，乙のようなモデ ル系のレオロジー的性質が, 実際の小麦粉ドウのそれを完全に再 現しえない点にある ${ }^{54)}$. しかし, 乙のような点を更に追究するこ とにより，実在の系のレオロジー的性質に及ぼす要因が明らかに なると考えられる。

\section{7. おわりに}

これまで述べてきたような人の食品に対する感覚的評価をはじ め. 種々の立場から, 食品研究の場でレオロジーのような物理学 的手法の導入は有用であるという認識は高まっている。しかし， 実際に食品研究者がかかわり合っている分野は, 例えば食糧生産 に始まってその貯蔵, 加工, 調理, 栄養生理, 衛生, 流通経済等 に至る広い範囲に及び，しかもそのいずれもが早急に解決しなけ ればならない多くの問題を抱えているのである。このような食品 研究の場に析出する多様性を, いかに系統的にとらえて整理し分 担するかが, 食品に関係のある人々にとって今後の重要な課題で ある。そのためには, まずてのような多様性の中で高度に専門化 された分野の中庸な位置づけと, 各分野の相互理解とが必要であ ろう。このような中で, レオロジーの導入が新しい食品研究分野 の創設につながるのではない。むしろ, その理論的背景と方法論 において高い普遍性を有するが故に, 多様な食品研究の中でのレ オロジーの有用性が認識されるのであり, 専門化された各分野の 
間の相互理解に対する架橋的役割がレオロジーに期待されるので ある。（昭和 52 年10月 25 日, 第25回レオロジー討論会にて講演）

\section{文}

\section{献}

1）松本幸雄, 山野善正編, “食品の物性, 第 1 ～ 3 集”（1975 ～1977）食品資材研究会.

2）田中咸子, 表面, 14，405（1976）.

3) Scott Blair, G.W., G. Watts, and H.J. Denham, Cereal Chem., 4, 63 (1927).

4）松本幸雄, 化学々工業, 28, 488 (1975).

5）松本幸雄, 化学, 31, 332 (1976).

6) Szczesniak, A.S., Food Technol., 17, 74 (1963).

7) Sherman, P., "Structure and Textural Properties of Foods", in A. Kramer and A.S. Szczesniak ed. "Texture Measurements of Foods", p. 52 (1973) D. Reidel Pub. Co., Holland.

8）曽根敏穈，“食品の粘稠性”，p. 1 (1966) 光琳書院.

9）河村洋二郎。“食品の物性認知に関する口腔機能”, 松本・ 山野編 “食品の物性第 2 集”, p. 85 (1976) 食品資材研究 会.

10) Scott Blair, G.W., "Elementary Rheology", p. 81 (1969) Academic Press, London.

11) Szczesniak, A.S., J. Food Sci., 28, 385 (1963).

12) Muller, H.G., "An Introduction to Food Rheology", p. 2 (1973) Heinemann, London.

13）吉川誠次, 西丸震哉, 田代豊久, 吉田正昭, 品質管理, 19, 66, 147 (1968).

14) Yoshikawa, S., S. Nishimaru, and M. Yoshida, $J$. Texture Studies, 1, 437, 443, 452 (1970).

15）吉川誠次, “テクスチャー用語の整理について”, 松本・山 野編“食品の物性第 2 集”, p. 191 (1976) 食品資材研究会.

16) Sherman, P., J. Food Sci., 34, 458 (1969).

17) Wood, F.W., S.C.I. Monograph, No. 27, p. 40 (1968).

18) Shama, F., C. Parkinson, and P. Sherman, J. Texture Studies, 4, 102 (1973).

19) Shama, F., and P. Sherman, J. Texture Studies, 4, 111 (1973).

20) Shama, F., and P. Sherman, Biorheology, 11, 453 (1974).

21) Kapsalis, J.G., A. Kramer, and A.S. Szczesniak, "Quantification of Objective and Sensory Texture Relations", in A. Kramer, and A.S. Szczesniak ed., "Texture Measurements of Foods", p. 130 (1973) D. Reidel Pub. Co., Holland.

22) Sherman, P., "Industrial Rheology", p. 33 (1970) Academic Press, London.

23）松本幸雄, 表面, 9, 711 (1971).

24) Matsumoto, S., J. Texture Studies, 5, 373 (1975).

25）岡部 魏, “食品のテクスチャーの測定法”, 松本・山野編 “食品の物性第 1 集”, p. 79 （1975）食品資材研究会.

26) Muller, H.G., “An Introduction to Food Rheology”, p. 25 (1973) Heinemann, London.
27) Voisey, P.W., "Recent Advances in Texture Test Instrumentation", presented at International Symposium on Food Texture and Rheology, held in Dec., 1977, London.

28) Proctor, B.E., S. Davison, G.J. Malecki, and M. Welch., Food Technol., 9, 471 (1955).

29) Friedman, H.H., J.E. Whitney, and A.S. Szczesniak, J. Food Sci., 28, 390 (1963).

30) Szczesniak, A.S., J. Food Sci., 28, 410 (1963).

31) Special Issure for Food Texture Profile, J. Texture Studies, 6, No. 1 (1975).

32) Hanai, T., D.A. Haydon, and J. Taylor, Proc. Roy. Soc., A281, 377 (1964).

33) Tien, H.T., J. Mol. Biol., 16, 577 (1966).

34) Bangham, A.D., M.M. Standish, and J.C. Watkins, J. Mol. Biol., 13, 238 (1965).

35) Papahadjopoulos, D., and N. Miller, Biochim. Biophys. Acta, 135, 624 (1967).

36) Van den Tempel, M., J. Colloid Sci., 16, 284 (1961).

37) 岡 小天, 深田栄一, 兽根敏麿, 材料試験, 10,333(1961).

38) Sone, T., J. Phys. Soc. Japan, 16, 961 (1961).

39) Avrami, M., J. Chem. Phys., 7, 1103 (1939); 8, 212 (1940); 9, 177 (1941).

40) Sato, Y., and T. Nakayama, J. Texture Studies, 1, 309 (1970).

41) Nakayama, T., and Y. Sato, Agr. Biol. Chem., 35, 208 (1971).

42) Nakayama, T., and Y. Sato, J. Texture Studies, 2, 75 (1971).

43) Nakayama, T., and Y. Sato, J. Texture Studies, 2, 475 (1971).

44) Nakayama, T., and Y. Sato, J. Texture Studies, 3, 359 (1972)

45）後藤廉平, 花井哲也編, “Sherman 博士論文選集”（1968）

46) Matsumoto, S., and P. Sherman, J. Colloid Interface Sci., 30, 525 (1969).

47) Matsumoto, S., Y. Kita, and D. Yonezawa, J. Colloid Interface Sci., 52, 353 (1976).

48) Matsumoto, S., M. Kohda, and S. Murata, J. Colloid Interface Sci., 62, 149 (1977).

49) Matsumoto, S., Y. Ueda, Y. Kita, and D. Yonezawa, Agr. Biol. Chem., 42, 739 (1978).

50) Matsumoto, S., and M. Kohda, "Rheological Properties of $W / O / W-T y p e$ Multiple-Phase Systems", presented at Internal Symposium on Food Texture and Rheology, held in Dec., 1977, London.

51）松本幸雄, 福田英憲, 米沢大造, 材料, 21, 387 (1972).

52）松本幸雄, 福田英憲, 米沢大造, 材料, 22, 427 (1973).

53）松本幸雄, 片山幸二, 米沢大造, 日本レオロジー学会誌, 2, 63 (1974).

54) Matsumoto, S., "Rheological Properties of Synthetic Flour Doughs", presented at International Symposium on Food Texture and Rheology, held in Dec., 1977, London. 